\title{
ANALISIS PENGARUH KUALITAS PRODUK, KUALITAS PELAYANAN DAN KEPERCAYAAN TERHADAP MINAT MENABUNG PADA PT BANK TABUNGAN NEGARA (PERSERO) TBK. CABANG SEMARANG
}

\author{
Novita Himatul Ulya *) \\ Embun Duriany Soemarso **) \\ Moch. Abdul Kodir **) \\ *) novitahima.nh@gmail.com
}

\begin{abstract}
This research aims to determine the significance of the variables influence the product quality, service quality and trust of the customers saving interest at PT Bank Tabungan Negara (Persero) Tbk. Cabang Semarang. This study uses primary data with questioner and secondary data. The population in this study are all savings customers at PT Bank Tabungan Negara (Persero) Tbk. Cabang Semarang. The sampling technique used was purposive sampling and accidental sampling.

The analysis model used in this research is Linear Regression Analysis Model, while the data analysis techniques using the $F$ test, $t$ test, and coefficient of determination (R2). In addition, it also tests the quality of the data in the form of tests validity and reliability, as well as a classical assumption test with normality tests, multicollinearity tests, heteroscedasticity tests, and autocorrelation tests. Test data indicate that the data is valid and reliable and free from irregularities classical assumptions.

The analysis and discussion showed that product quality, service quality and trust simulataniously significant influence customers saving interest at PT Bank Tabungan Negara (Persero) Tbk. Cabang Semarang. Variable service quality and trust partially significant influence customer saving interest, while the variable product quality not significantly influence customer saving interest at PT Bank Tabungan Negara (Persero) Tbk. Cabang Semarang.
\end{abstract}

Keywords: Interest in saving, product quality, service quality and trust.

*) Mahasiswa Tugas Akhir Prodi Keuangan dan Perbankan Jurusan Akuntansi Politeknik Negeri Semarang

**) Dosen Jurusan Akuntansi Politeknik Negeri Semarang

\section{PENDAHULUAN}

\section{Latar Belakang}

Perbankan memiliki peran penting dalam perekonomian suatu negara. Semakin berkembang industri perbankan, maka semakin baik pula pertumbuhan ekonomi negara tersebut. Menurut Undang-undang Republik Indonesia Nomor 10 Tahun 1998 tentang Perbankan, Bank adalah sebuah badan usaha yang menghimpun dana dari masyarakat dalam bentuk simpanan dan menyalurkannya kepada masyarakat dalam bentuk kredit dan atau bentuk-bentuk lain dengan tujuan untuk meningkatkan taraf hidup orang banyak. Sumber penghimpunan dana bank berasal dari beberapa sumber. Salah satu sumber dana bank yang berperan bagi kelangsungan kegiatan operasional bank adalah dana dari pihak ketiga yaitu 
tabungan. Tabungan merupakan sumber dana yang murah dan berpengaruh besar terhadap operasional bank. Oleh karena itu, semakin banyak nasabah yang menyimpan dananya maka semakin berkembang bank tersebut.

Berdasarkan hasil penelitian melalui survei yang dilakukan oleh Marketing Research Indonesia (MRI) dalam “Bank Service Excellence Monitor (BSEM) 2017-2018”, tentang Performa terbaik Customer Services 10 Bank menunjukkan bahwa PT Bank Tabungan Negara (Persero) Tbk. pada tahun 2017 dan 2018 menempati posisi peringkat ke-5. Persentase mengalami penurunan dari $64,18 \%$ pada tahun 2017 menjadi 62,23\% pada tahun 2018 . Hal ini berarti PT Bank Tabungan Negara (Persero) Tbk. harus lebih meningkatkan kualitas produk dan pelayanannya terhadap nasabah. Agar tetap mendapatkan kepercayaan nasabah untuk tetap menggunakan produk dan jasa bank tersebut.

Dalam menggunakan produk dan jasa bank, nasabah juga mempertimbangkan pada DPK Bank Umum. Berdasarkan data DPK 10 Bank Asing dan Campuran diantara Bank Umum (Non konsolidasi) Per September 2017 menunjukkan bahwa PT Bank Tabungan Negara (Persero) Tbk. memiliki pertumbuhan DPK yang bagus dan dalam kategori tinggi dibanding bank-bank lainnya. Hal ini penting untuk diperhatikan PT Bank Tabungan Negara (Persero) Tbk. dalam mempertahankan prestasi tersebut sehingga minat nasabah untuk menabung di bank tersebut tetap meningkat.

Meskipun dalam data DPK 10 Bank Asing dan Campuran diantara Bank Umum (Non konsolidasi) Per September 2017-2018 menunjukkan bahwa PT Bank Tabungan Negara (Persero) Tbk. memiliki DPK yang bagus dan lebih tinggi dibanding bank-bank lainnya, namun dalam hal performa terbaik Customer Service pada tahun 2017 dan 2018 masih menempati posisi peringkat ke-5. Hal ini menunjukkan bahwa kualitas pelayanan PT Bank Tabungan Negara (Persero) Tbk. masih perlu ditingkatkan kembali.

Mengingat pentingnya minat menabung nasabah dan masing-masing variabel yang terkait dengan minat menabung nasabah, dan keragaman hasil penelitian serta adanya fenomena bisnis maka layak dilakukan penelitian kembali untuk menganalisis pengaruh variabel-variabel independen diantaranya kualitas produk, kualitas pelayanan dan kepercayaan terhadap variabel dependen yaitu minat menabung nasabah, dengan obyek penelitian pada PT Bank Tabungan Negara (Persero) Tbk. Cabang Semarang.

Penelitian ini bertujuan untuk menganalisis (1) signifikansi pengaruh variabel kualitas produk, kualitas pelayanan, dan kepercayaan terhadap minat nasabah menabung pada PT Bank Tabungan Negara (Persero) Tbk. Cabang Semarang, (2) signifikansi pengaruh variabel kualitas produk terhadap minat nasabah menabung pada PT Bank Tabungan Negara (Persero) Tbk. 
Cabang Semarang, (3) signifikansi pengaruh variabel kualitas pelayanan terhadap minat nasabah menabung pada PT Bank Tabungan Negara (Persero) Tbk. Cabang Semarang, (4) signifikansi pengaruh variabel kepercayaan terhadap minat menabung pada PT Bank Tabungan Negara (Persero) Tbk. Cabang Semarang.

\section{KAJIAN TEORI}

\section{Bank}

Merupakan sebuah badan usaha yang menghimpun dana dari masyarakat dalam bentuk simpanan dan menyalurkannya kepada masyarakat dalam bentuk kredit dan atau bentuk-bentuk lain dengan tujuan untuk meningkatkan taraf hidup orang banyak (Undang-undang Republik Indonesia Nomor 10 Tahun 1998 tentang Perbankan). Bank umum adalah bank yang melaksanakan kegiatan usaha secara konvensional dan atau berdasarkan prinsip syariah, yang dalam kegiatannya memberikan jasa dalam lalu lintas pembayaran (Undang-undang Republik Indonesia Nomor 10 Tahun 1998 tentang Perbankan).

\section{Tabungan}

Merupakan simpanan yang penarikannya hanya dapat dilakukan menurut syarat tertentu yang disepakati, tetapi tidak dapat ditarik dengan cek, bilyet giro, dan atau alat lainnya yang dipersamakan dengan itu (Undang-undang Republik Indonesia Nomor 10 Tahun 1998 tentang Perbankan).

\section{Nasabah}

Pengertian nasabah secara umum menurut Undang-undang Republik Indonesia Nomor 10 Tahun 1998 tentang perbankan yaitu pihak yang menggunakan jasa bank. Undang-undang Republik Indonesia Nomor 10 Tahun 1998 tentang perbankan pasal 1 membagi nasabah menjadi dua macam:

1. Nasabah Penyimpan, yaitu nasabah yang menempatkan dananya di bank dalam bentuk simpanan berdasarkan perjanjian bank dengan nasabah yang bersangkutan.

2. Nasabah Debitur, yaitu nasabah yang memperoleh fasilitas kredit atau pembiayaan berdasarkan prinsip syariah atau yang dipersamakan dengan perjanjian antara bank dan nasabah yang bersangkutan.

\section{Minat Menabung}

Merupakan rasa suka (senang) dan rasa tertarik pada kegiatan menabung tanpa ada yang menyuruh dan biasanya ada kecenderungan untuk mencari objek yang disenangi tersebut (Pandji dalam Astuti dan Mustikawati, 2013). Minat menabung nasabah adalah keinginan yang datang dari diri nasabah untuk menggunakan produk/jasa bank atau melakukan penyimpanan atas uang mereka di bank dengan tujuan tertentu (Astuti dan Mustikawati, 2013). 


\section{Kualitas Produk}

Kualitas merupakan perpaduan antara sifat dan karakteristik yang menentukan sejauh mana keluaran/input dapat memenuhi persyaratan kebutuhan pelanggan (Lupiyoadi, 2013:212). Produk didefinisikan Kotler dan Amstrong (2008) sebagai semua hal yang dapat ditawarkan kepada pasar untuk menarik perhatian, akuisisi, penggunaan, atau konsumsi yang dapat memuaskan suatu keinginan atau kebutuhan. Kualitas produk adalah kemampuan sebuah produk dalam memperagakan fungsinya, hal itu termasuk keseluruhan durabilitas, reliabilitas, ketepatan, kemudahan pengoperasian dan reparasi produk juga atribut produk lainnya (Kotler dan Amstrong, 2008:283).

\section{Kualitas Pelayanan}

Menurut Lupiyoadi dan A. Hamdani (2006:181) kualitas pelayanan adalah seberapa jauh perbedaan kemampuan memberikan jasa kepada nasabah dan layanan yang sesungguhnya diharapkan nasabah.

\section{Kepercayaan}

Didefinisikan sebagai persepsi akan kesediaan satu pihak untuk menerima risiko dari tindakan pihak lain berdasarkan harapan bahwa pihak lain akan melakukan tindakan penting untuk pihak yang mempercayainya, terlepas dari kemampuan untuk mengawasi dan mengendalikan tindakan pihak yang dipercaya. (Jeniffer dalam Nurul Khotimah, 2018).

\section{HUBUNGAN ANTAR VARIABEL}

Hubungan Kualitas Produk, kualitas pelayanan, dan kepercayaan secara simultan mempunyai pengaruh yang signifikan terhadap minat nasabah menabung.

Hasil penelitian yang dilakukan oleh Dedy Trisnadi dan Ngadino Surip (2013), menunjukkan bahwa kualitas produk tabungan dan kualitas pelayanan berpengaruh signifikan terhadap minat menabung terhadap minat menabung nasabah pada Bank CIMB Niaga.

Berdasarkan uraian diatas yang didukung oleh hasil penelitian diatas, maka hipotesis yang diajukan adalah sebagai berikut :

H1 = Variabel kualitas produk, kualitas pelayanan, dan kepercayaan secara simultan mempunyai pengaruh yang signifikan terhadap minat nasabah menabung.

\section{Hubungan kualitas produk secara parsial mempunyai pengaruh yang signifikan terhadap minat menabung nasabah.}

Menurut hasil penelitian yang dilakukan oleh Dedy Trisnadi dan Ngadino Surip (2013), menunjukkan bahwa kualitas produk tabungan dan kualitas pelayanan berpengaruh signifikan terhadap minat menabung terhadap minat menabung nasabah pada Bank CIMB Niaga. 
Berdasarkan uraian diatas yang didukung oleh hasil penelitian diatas, maka hipotesis yang diajukan adalah sebagai berikut :

$\mathrm{H} 2$ = Variabel kualitas produk secara parsial mempunyai pengaruh yang signifikan terhadap minat menabung nasabah.

Hubungan kualitas pelayanan secara parsial mempunyai pengaruh yang signifikan terhadap minat menabung nasabah.

Hasil penelitian Tri Astuti dan Rr. Indah Mustikawati (2013), menunjukkan bahwa persepsi nasabah tentang kualitas pelayanan berpengaruh positif dan signifikan terhadap minat menabung nasabah Bank BRI cabang Sleman.

H3 = Variabel kualitas pelayanan secara parsial mempunyai pengaruh yang signifikan terhadap minat nasabah menabung.

\section{Hubungan kepercayaan secara parsial mempunyai pengaruh yang signifikan terhadap} minat menabung nasabah.

Menurut penelitian Yohana Neysa Setyawan dan Edwin Japarianto (2014), menunjukkan bahwa kepercayaan terbukti berpengaruh signifikan terhadap minat menabung di Bank Danamon. Untuk itu, hipotesis penelitian 1 yang menyatakan bahwa kepercayaan nasabah berpengaruh terhadap minat menabung di Bank Danamon adalah terbukti.

H4 = Variabel kepercayaan secara parsial mempunyai pengaruh yang signifikan terhadap minat menabung nasabah.

\section{Kerangka Pemikiran Teoritis}

Berdasarkan hasil kajian pustaka dan penelitian-penelitian terdahulu yang telah dikembangkan, maka dikembangkan kerangka pemikiran teoritis yang mendasari penelitian ini. 


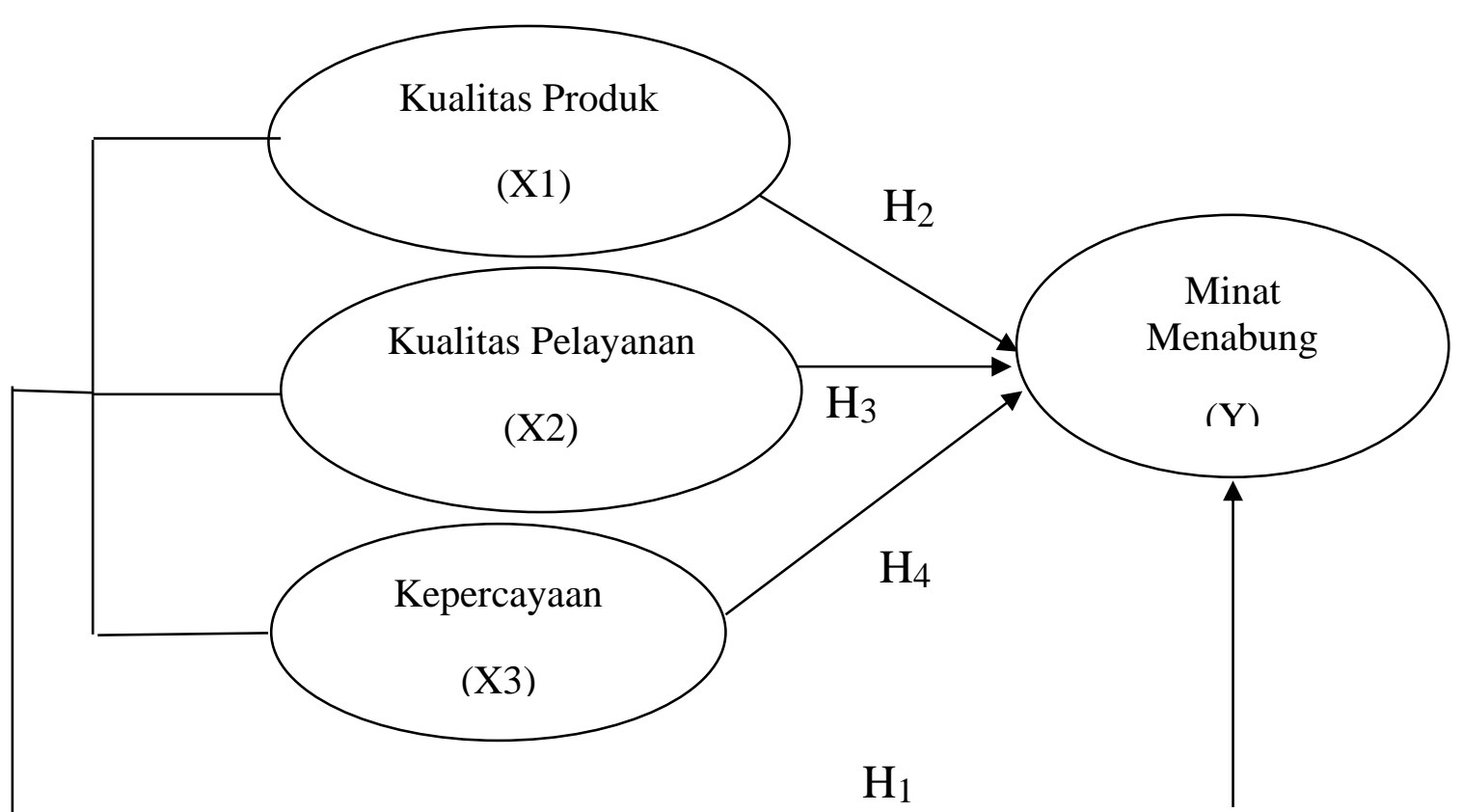

Sumber : Penelitian terdahulu yang dikembangkan, 2019

\section{Gambar 1}

\section{Kerangka Pemikiran Teoritis}

\section{METODE PENELITIAN}

\section{Desain Penelitian}

Desain penelitian ini menggunakan penelitian terapan kausal. Jenis penelitian ini dilakukan dengan tujuan untuk mengukur hubungan-hubungan antara variabel riset atau berguna untuk menganalisis bagaimana suatu variabel mempengaruhi variabel lain (Umar, 2003:40).

\section{Populasi}

Menurut Hasan (2010:84) menyatakan bahwa populasi adalah totalitas dari semua objek atau individu yang memiliki karakteristik tertentu, jelas dan lengkap yang akan diteliti. Populasi dalam penelitian ini adalah seluruh nasabah tabungan pada PT Bank Tabungan Negara (Persero) Tbk. Cabang Semarang.

\section{Sampel}

Menurut Simamora (2004:192), sampel sering disebut dengan contoh. Sampel merupakan bagian dari populasi. Sampel bias juga disebut sebagai sub group populasi yang dipilih untuk dilibatkan dalam penelitian. Pada penelitian ini, penentuan jumlah sampel dilakukan berdasarkan kriteria yang dinyatakan oleh Roscoe (1975) dalam Ferdinand (2006). Bahwa apabila menggunakan teknik analisis regresi, maka jumlah sampel yang diambil ditentukan sebesar 25 kali jumlah variabel independen yang digunakan.

Sampel $=\mathrm{n} \times 25$

Sampel $=3 \times 25=75$ 
Keterangan :

$\mathrm{n}=$ jumlah variabel independen

Teknik pengambilan sampel yang digunakan dalam penelitian ini adalah dengan non probability sampling yang berupa purposive sampling (Judgment Sampling). Sampel ini ditentukan berdasarkan jumlah dari nasabah tabungan PT Bank Tabungan Negara (Persero) Tbk. Cabang Semarang yang dapat mewakili pengisian kuesioner.

Batasan-batasan sampel yang digunakan dalam penelitian ini yaitu sebagai berikut:

1. Nasabah tabungan PT Bank Tabungan Negara (Persero) Tbk. Cabang Semarang.

2. Nasabah tabungan yang aktif bertransaksi pada PT Bank Tabungan Negara (Persero) Tbk. Cabang Semarang.

\section{Metode Analisis Data}

Dalam Tugas Akhir ini penulis menggunakan metode analisis regresi linear berganda (Multiple Linear Regression Analysis Model). Adapun persamaan bentuk matematis analisis regresi linear berganda sebagai berikut :

$\mathrm{Y}=\mathrm{a}+\mathrm{b} 1 \mathrm{X} 1+\mathrm{b} 2 \mathrm{X} 2+\mathrm{b} 3 \mathrm{X} 3+\mathrm{e}$

Dimana :

Y $\quad=$ variabel dependen

a $\quad=$ konstanta atau intercept persamaan regresi

$\mathrm{b} 1, \mathrm{~b} 2, \mathrm{~b} 3=$ koefisien regresi atau slope variabel independen

$\mathrm{X} 1, \mathrm{X} 2, \mathrm{X} 3 \quad$ = variabel independen

$\mathrm{e}$

$$
\text { = error }
$$




\section{HASIL DAN PEMBAHASAN}

Tabel 1 Uji Validitas

\begin{tabular}{|c|c|c|c|c|}
\hline No. & Variabel \& Indikator & r hitung & $\mathrm{r}$ table & Keterangan \\
\hline 1. & $\begin{array}{c}\text { Kualitas Produk } \\
\text { X1.1 } \\
\text { X1.2 } \\
\text { X1.3 } \\
\text { X1.4 } \\
\text { X1.5 }\end{array}$ & $\begin{array}{l}0,877 \\
0,910 \\
0,913 \\
0,884 \\
0,863\end{array}$ & $\begin{array}{l}0,2272 \\
0,2272 \\
0,2272 \\
0,2272 \\
0,2272\end{array}$ & $\begin{array}{l}\text { Valid } \\
\text { Valid } \\
\text { Valid } \\
\text { Valid } \\
\text { Valid }\end{array}$ \\
\hline 2. & $\begin{array}{c}\text { Kualitas Pelayanan } \\
\text { X2.1 } \\
\text { X2.2 } \\
\text { X2.3 } \\
\text { X2.4 } \\
\text { X2.5 } \\
\end{array}$ & $\begin{array}{l}0,860 \\
0,880 \\
0,920 \\
0,917 \\
0,872 \\
\end{array}$ & $\begin{array}{l}0,2272 \\
0,2272 \\
0,2272 \\
0,2272 \\
0,2272\end{array}$ & $\begin{array}{l}\text { Valid } \\
\text { Valid } \\
\text { Valid } \\
\text { Valid } \\
\text { Valid }\end{array}$ \\
\hline 3. & $\begin{array}{c}\text { Kepercayaan } \\
\text { X3.1 } \\
\text { X3.2 } \\
\text { X3.3 } \\
\end{array}$ & $\begin{array}{l}0,922 \\
0,953 \\
0,928 \\
\end{array}$ & $\begin{array}{l}0,2272 \\
0,2272 \\
0,2272 \\
\end{array}$ & $\begin{array}{l}\text { Valid } \\
\text { Valid } \\
\text { Valid } \\
\end{array}$ \\
\hline 4. & $\begin{array}{c}\text { Minat Menabung } \\
\text { Y1 } \\
\text { Y2 } \\
\text { Y3 }\end{array}$ & $\begin{array}{l}0,923 \\
0,943 \\
0,902 \\
\end{array}$ & $\begin{array}{l}0,2272 \\
0,2272 \\
0,2272 \\
\end{array}$ & $\begin{array}{l}\text { Valid } \\
\text { Valid } \\
\text { Valid }\end{array}$ \\
\hline
\end{tabular}

Sumber : Data primer yang diolah, 2019

Berdasarkan Tabel 1, uji validitas memperlihatkan $\mathrm{r}$ hitung indikator variabel kualitas produk, kualitas pelayanan, kepercayaan dan minat menabung nilai $r_{h i t u n g}>r_{\text {tabel }}$ dengan demikian indikator yang digunakan sebagai alat ukur variabel dinyatakan valid.

Tabel 2 Uji Reliabilitas

\begin{tabular}{|l|c|c|}
\hline \multicolumn{1}{|c|}{ Variabel } & Cronbach Alpha & Keterangan \\
\hline Kualitas Produk (X1) & 0.934 & Reliabel \\
\hline Kualitas Pelayanan (X2) & 0.934 & Reliabel \\
\hline Kepercayaan (X3) & 0.927 & Reliabel \\
\hline Minat Menabung (Y) & 0.913 & Reliabel \\
\hline
\end{tabular}

Sumber : Data primer yang diolah, 2019

Berdasarkan Tabel 2 dapat dilihat bahwa nilai Cronbach Alpha (tingkat reliabilitas) untuk masing-masing variabel $>0,07$. Sehingga indikator atau kuesioner tersebut reliabel sebagai alat ukur variabel data. 


\section{Uji Normalitas}

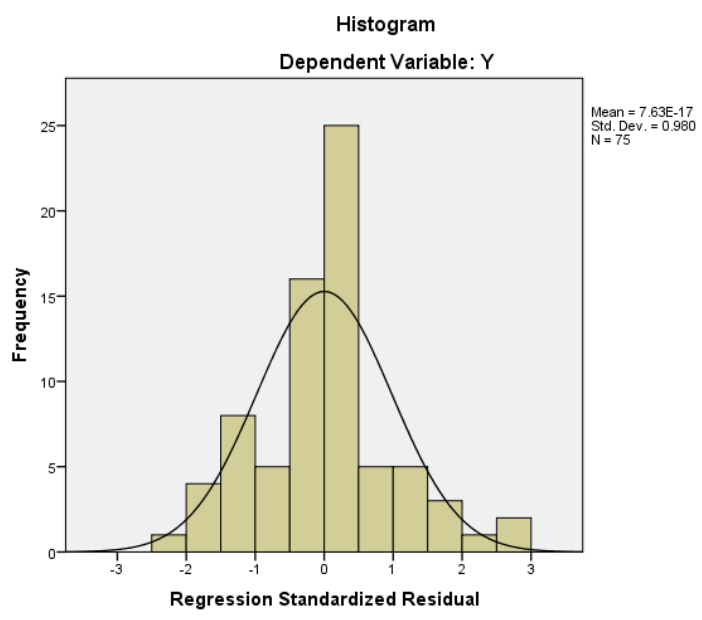

Sumber: Data primer yang diolah, 2019

Gambar 2 Grafik Histogram Normalitas

Dengan melihat grafik histogram pada Gambar 4.1 bahwa residual terdistribusi secara normal dan berbentuk simetris tidak mengarah ke kanan atau ke kiri. Hal ini dapat disimpulkan bahwa residual terdistribusi secara normal.

\section{Uji Multikolineritas}

Dalam penelitian ini menunjukkan bahwa tidak ada variabel independen yang memiliki nilai VIF lebih dari 10 . Hasil perhitungan juga didukung oleh nilai tolerance lebih dari 0,10 yang artinya tidak ada korelasi antar variabel independen.

\section{Uji Heteroskedastisitas}

Dalam penelitian ini dapat ditarik kesimpulan bahwa tidak terjadi heteroskedastisitas pada model regresi. Hal ini karena berdasarkan gambar, dimana titik-titik yang ada dalam grafik scatterplot tersebar di atas dan dibawah angka 0 pada sumbu Y. Berdasarkan hasil uji glejser menunjukkan bahwa nilai ABSRES1 dengan nilai signifikan > 5\% maka model regresi tidak mengandung adanya heteroskedastisitas.

\section{Uji Autokorelasi}

Berdasarkan hasil pengujian, menunjukkan bahwa hasil uji autokorelasi pada model regresi sebesar 2.269. nilai tersebut jika dibandingkan dengan menggunakan nilai tabel Durbin Watson dengan menggunakan derajat kepercayaan $5 \%$ dari jumlah sampel $75 . \mathrm{N}=75$ dan $\mathrm{K}$ (jumlah variabel bebas) $=3$. Nilai table DW dl $=1,5323 \mathrm{dan} d u=1,705$. Dengan syarat $\mathrm{du}<$ DW < 4-du, jadi 1,705 < 2,269 < 2,295, maka dapat disimpulkan tidak terjadi autokorelasi.

\section{Analisis Regresi Linear Berganda}

Analisis ini digunakan untuk mengetahui adanya pengaruh antara variabel kualitas produk, kualitas pelayanan dan kepercayaan terhadap minat menabung nasabah. 
Tabel 3 Hasil Regresi Linear Berganda

Coefficients ${ }^{\mathrm{a}}$

\begin{tabular}{|c|c|c|c|c|c|c|}
\hline \multirow{2}{*}{\multicolumn{2}{|c|}{ Model }} & \multicolumn{2}{|c|}{$\begin{array}{c}\text { Unstandardized } \\
\text { Coefficients }\end{array}$} & $\begin{array}{c}\text { Standardized } \\
\text { Coefficients }\end{array}$ & \multirow[t]{2}{*}{$\mathrm{t}$} & \multirow[t]{2}{*}{ Sig. } \\
\hline & & $\mathrm{B}$ & Std. Error & Beta & & \\
\hline \multirow{4}{*}{1} & (Constant) & .605 & .647 & & .936 & .353 \\
\hline & Kualitas Produk & .137 & .079 & .224 & 1.744 & .086 \\
\hline & Kualitas Pelayanan & .250 & .073 & .415 & 3.435 & .001 \\
\hline & Kepercayaan & .276 & .109 & .278 & 2.540 & .013 \\
\hline
\end{tabular}

a. Dependent Variable: Minat Menabung

Sumber : Data primer yang diolah, 2019

Berdasarkan hasil regresi linear berganda pada Tabel 4.3 diperoleh persamaan regresi yaitu :

\section{Minat Menabung $=\quad 0,605+0,137$ Kualitas Produk + 0,250 Kualitas Pelayanan + 0,276 Kepercayaan + e}

Tabel 4 Hasil Uji F

ANOVA $^{\mathrm{a}}$

\begin{tabular}{|rl|r|r|r|r|l|}
\hline \multicolumn{1}{|l|}{ Model } & \multicolumn{1}{c|}{$\begin{array}{c}\text { Sum of } \\
\text { Squares }\end{array}$} & Df & Mean Square & F & Sig. \\
\hline \multirow{3}{*}{1} & Regression & 209.719 & 3 & 69.906 & 67.229 & $.000^{\mathrm{b}}$ \\
& Residual & 73.827 & 71 & 1.040 & & \\
& Total & 283.547 & 74 & & & \\
\hline
\end{tabular}

a. Dependent Variable: Minat Menabung

b. Predictors: (Constant), Kepercayaan, Kualitas Pelayanan, Kualitas Produk

Sumber : Data primer yang diolah, 2019

Berdasarkan hasil uji statistik $\mathrm{F}$ pada Tabel 4.4 nilai $\mathrm{F}$ hitung sebesar 67,229 dan signifikansi sebesar 0,000 yang apabila dibandingkan dengan $\mathrm{F}$ tabel (tingkat signifikansi 5\%, jumlah data 75, dan jumlah variabel independen 3) yaitu 2,73, maka nilai F hitung lebih besar dari $\mathrm{F}$ tabel, demikian juga dengan probabilitas kesalahannya sebesar 0,000 yang berada di bawah 0,05 atau 5\%, sehingga Ho ditolak dan Ha diterima. Hal ini menunjukkan bahwa variabel kualitas produk, kualitas pelayanan dan kepercayaan secara simultan berpengaruh signifikan terhadap minat menabung nasabah. Hipotesis 1 dinyatakan diterima.

\section{Uji t}

Tabel 5 Hasil Uji t

Coefficients $^{\mathrm{a}}$

\begin{tabular}{|rl|r|r|l|}
\hline Model & & \multicolumn{1}{c|}{$\mathrm{T}$} & \multicolumn{1}{c|}{ Sig. } & \multicolumn{1}{c|}{ Keterangan } \\
\hline \multirow{3}{*}{1} & (Constant) & .936 & .353 & \\
\cline { 2 - 4 } & X1 & 1.744 & .086 & Berpengaruh Tidak Signifikan \\
& X2 & 3.435 & .001 & Berpengaruh Signifikan \\
& X3 & 2.540 & .013 & Berpengaruh Signifikan \\
\hline
\end{tabular}

a. Dependent Variable: Minat Menabung

Sumber : Data primer yang diolah, 2019 
Berdasarkan hasil tersebut maka dapat ditarik kesimpulan sebagai berikut :

1. Variabel Kualitas Produk (Pengujian Hipotesis 2)

Berdasarkan hasil perhitungan diperoleh nilai t hitung sebesar 1,744 dengan tingkat signifikansi sebesar 0,086 (di atas 0,05) atau t hitung lebih kecil dari t tabel yaitu 1,994, sehingga Ho diterima dan Ha ditolak. Hal ini menunjukkan bahwa variabel kualitas produk secara parsial berpengaruh secara tidak signifikan dan koefisien regresi dari variabel kualitas produk bertanda $(+1,744)$ dan searah terhadap minat menabung nasabah pada PT Bank Tabungan Negara (Persero) Tbk. Cabang Semarang. Berdasarkan hasil perhitungan tersebut maka hipotesis 2 dinyatakan ditolak.

2. Variabel Kualitas Pelayanan (Pengujian Hipotesis 3)

Berdasarkan hasil perhitungan diperoleh nilai thitung sebesar 3,435 dengan tingkat signifikansi sebesar 0,001 (di bawah 0,05) atau t hitung lebih besar dari t tabel yaitu 1,994, sehingga Ho ditolak dan Ha diterima. Hal ini menunjukkan bahwa variabel kualitas pelayanan secara parsial berpengaruh secara signifikan dan koefisien regresi dari variabel kualitas produk bertanda $(+3,435)$ dan searah terhadap minat menabung nasabah pada PT Bank Tabungan Negara (Persero) Tbk. Cabang Semarang. Berdasarkan hasil perhitungan tersebut maka hipotesis 3 dinyatakan diterima.

3. Variabel Kepercayaan (Pengujian Hipotesis 4)

Berdasarkan hasil perhitungan diperoleh nilai t hitung sebesar 2,540 dengan tingkat signifikansi sebesar 0,013 (di bawah 0,05) atau t hitung lebih besar dari t tabel yaitu 1,994, sehingga Ho ditolak dan Ha diterima. Hal ini menunjukkan bahwa variabel kepercayaan secara parsial berpengaruh secara signifikan dan koefisien regresi dari variabel kualitas produk bertanda $(+2,540)$ dan searah terhadap minat menabung nasabah pada PT Bank Tabungan Negara (Persero) Tbk. Cabang Semarang. Berdasarkan hasil perhitungan tersebut maka hipotesis 4 dinyatakan diterima.

\section{Koefisien Determinasi $\left(\mathbf{R}^{2}\right)$}

Tabel 6 Hasil Uji Koefisien Determinasi $\left(\mathbf{R}^{2}\right)$ Model Summary ${ }^{\mathrm{b}}$

\begin{tabular}{|l|r|r|r|r|r|}
\hline Model & \multicolumn{1}{|c|}{$\mathrm{R}$} & R Square & $\begin{array}{c}\text { Adjusted R } \\
\text { Square }\end{array}$ & $\begin{array}{c}\text { Std. Error of the } \\
\text { Estimate }\end{array}$ & Durbin-Watson \\
\hline 1 & $.860^{\mathrm{a}}$ & .740 & .729 & 1.0197 & 2.269 \\
\hline
\end{tabular}

a. Predictors: (Constant), Kepercayaan, Kualitas Pelayanan, Kualitas Produk

b. Dependent Variable: Minat Menabung

Sumber : Data primer yang diolah, 2019 
Berdasarkan hasil uji koefisien determinasi (R2) pada Tabel 4.6 didapat nilai Adjusted $R$ Square sebesar 0,729 hal ini menunjukkan bahwa 72,9\% variasi minat menabung nasabah dapat dijelaskan oleh variasi dari ketiga variabel bebas, sedangkan sisanya 27,1\% dijelaskan oleh variasi variabel yang lain di luar penelitian ini.

\section{PENUTUP}

\section{Kesimpulan}

Berdasarkan hasil analisis data dan pembahasan yang telah dikemukakan pada bab IV dapat diambil kesimpulan sebagai berikut :

1. Kualitas produk, kualitas pelayanan dan kepercayaan secara simultan berpengaruh signifikan terhadap minat menabung nasabah pada PT Bank Tabungan Negara (Persero) Tbk. Cabang Semarang.

2. Kualitas produk secara parsial berpengaruh tidak signifikan terhadap minat menabung nasabah pada PT Bank Tabungan Negara (Persero) Tbk. Cabang Semarang.

3. Kualitas pelayanan secara parsial berpengaruh signifikan terhadap minat menabung nasabah pada PT Bank Tabungan Negara (Persero) Tbk. Cabang Semarang.

4. Kepercayaan secara parsial berpengaruh signifikan terhadap minat menabung nasabah pada PT Bank Tabungan Negara (Persero) Tbk. Cabang Semarang.

\section{Implikasi Manajerial}

Saran kepada para pengambil kebijakan pada PT Bank Tabungan Negara (Persero) Tbk.

Cabang Semarang untuk peningkatan minat menabung nasabah sebagai berikut :

1. Variabel kualitas pelayanan berpengaruh signifikan terhadap minat menabung nasabah pada PT Bank Tabungan Negara (Persero) Tbk. Cabang Semarang. Namun, PT Bank Tabungan Negara (Persero) Tbk. Cabang Semarang harus memperhatikan, mempertahankan dan meningkatkan kualitas pelayanan yang terbaik kepada nasabah. Baik dari sarana prasarana maupun pegawai front office. Hendaknya memberi arahan yang sopan apabila jasa yang dibutuhkan nasabah sedang tidak bisa dilakukan dengan alasan yang jelas. Dan sebaiknya tidak membuat nasabah menunggu antrean terlalu lama.

2. Variabel Kepercayaan berpengaruh signifikan terhadap minat menabung nasabah pada PT Bank Tabungan Negara (Persero) Tbk. Cabang Semarang. Namun, PT Bank Tabungan Negara (Persero) Tbk. Cabang Semarang harus memperhatikan, mempertahankan dan meningkatkan kepercayaan yang telah diberikan nasabah. Dengan tetap melayani nasabah dengan penuh kejujuran, kehati-hatian dan perhatian. 
Memberikan pelayanan penyelesaian transaksi yang cepat, aman dan tepat. Sehingga kepercayaan nasabah terhadap bank terus terjalin.

3. Selain itu variabel kualitas produk tidak berpengaruh signifikan terhadap minat menabung nasabah pada PT Bank Tabungan Negara (Persero) Tbk. Cabang Semarang. Namun, PT Bank Tabungan Negara (Persero) Tbk. Cabang Semarang harus memperhatikan, mempertahankan dan meningkatkan kualitas produk serta melakukan inovasi agar tidak kalah saing dengan bank lainnya, melakukan sosialisasi produk tabungan dan menambahkan fasilitas-fasilitas pendukung yang dapat menarik minat nasabah untuk menabung di bank tersebut.

\section{DAFTAR PUSTAKA}

Astuti, Tri dan Rr. Indah Mustikawati. 2013. "Pengaruh Persepsi Nasabah Tentang Tingkat Suku Bunga, Promosi dan Kualitas Pelayanan Terhadap Minat Menabung Nasabah”. Jurnal Nominal. Volume 2. Nomor 1.

Bank Indonesia. 1998. Undang-Undang Republik Indonesia No. 10 Tahun 1998. Tentang Perbankan. Jakarta: Sinar Grafika.

Cahyani, Asih Fitri et. al. 2013. "Pengaruh Persepsi Bunga Bank dan Kualitas Pelayanan Terhadap Minat Menabung Pada Bank BNI Syariah di Kota Semarang”. Diponegoro Journal of Social and Politic. Hal: 1-8.

Ferdinand, Augusty. 2006. Metode Penelitian Manajemen. Semarang: Badan Penerbit Universitas Diponegoro.

Ghozali, Imam. 2006. Aplikasi Analisis Multivariate dengan Program SPSS. Semarang: Badan Penerbit Universitas Diponegoro.

-----------------. 2018. Aplikasi Analisis Multivariate dengan Program IBM SPSS 25. Semarang: Badan Penerbit UNDIP.

Hasan, Iqbal. 2010. Analisis Data Penelitian dengan Statistik. Jakarta: PT Bumi Aksara.

Khotimah, Nurul. 2018. "Pengaruh Religiusitas, Kepercayaan, Citra Perusahaan, dan System Bagi Hasil terhadap Minat Nasabah Menabung dan Loyalitas di Bank Syariah Mandiri”. Jurnal Ilmu Ekonomi \& Manajemen. Volume 5. Nomor 1. Hal: 37-48.

Kotler dan Amstrong. 2004. Dasar-dasar Pemasaran. Jilid 1. Jakarta: Prenhallindo.

Lupiyoadi, Rambat dan A. Hamdani. 2006. Manajemen Pemasaran Jasa. Edisi Kedua. Jakarta:

Salemba Empat.

Majalah Infobank. Mei 2018.

Majalah Infobank. Juni 2019. 
Marzuki. 2005. Metodologi Riset Panduan Penelitian Bidang Bisnis dan Sosial. Edisi Kedua. Yogyakarta: Ekosiana.

Romdhoni, Abdul Haris dan Dita Ratnasari. 2018. "Pengaruh Pengetahuan, Kualitas Pelayanan, Produk, dan Religiusitas terhadap Minat Nasabah untuk Menggunakan Produk Simpanan pada Lembaga Keuangan Mikro Syariah”. Jurnal Ilmiah Ekonomi Islam. Volume 4. Nomor 2. Hal: 136-147.

Setyawan, Yohana Neysa dan Edwin Japarianto. 2014. “Analisa Pengaruh Kepercayaan, Jaminan Rasa Aman, dan Aksebilitas terhadap Minat Menabung Nasabah Bank Danamon di Surabaya”. Jurnal Manajemen Pemasaran. Volume 2. Nomor 1.

Sugiyono. 2011. Metode Penelitian Kuantitatif, Kualitatif dan R\&D. Bandung: Alfabeta.

Tjiptono, Fandy. 2008. Strategi Pemasaran. Edisi Pertama. Yogyakarta: ANDI Offset.

Trisnadi, Dedy dan Ngadino Surip. 2013. "Pengaruh Kualitas Produk Tabungan dan Kualitas Layanan Terhadap Minat Menabung Kembali di CIMB Niaga”. Jurnal MIX. Volume 6. Nomor 3.

Umar. Husein. 2003. Metode Riset Perilaku Konsumen Jasa. Jakarta: Ghalia Indonesia. 2002. Metode Perilaku Konsumen Jasa. Jakarta: Ghalia Indonesia.

www.btn.co.id

Yulianti dan Ignatus Soni Kurniawan. 2016. "Pengaruh Periklanan, Kualitas Pelayanan, Jaminan Rasa Aman, dan Hubungan Masyarakat terhadap Minat Menabung pada Nasabah BMT Al Ikhwan Kantor Cabang Condong Catur”. Jurnal Manajemen. Volume 6. Nomor 2. Hal: 29-42. 